\title{
The Influence of Transformational Leadership and Employee Integrity through Organizational Citizenship Behavior (OCB) on Employee Innovation in Regency / City Inspectorates In North Sulawesi Province
}

\author{
Praseno Hadi \\ Universitas Negeri Jakarta \\ Email: prasenohadi_im10s3@mahasiswa.unj.ac.id \\ Hamidah \\ Universitas Negeri Jakarta \\ Email: hamidah@unj.ac.id \\ David Paul Saerang \\ Universitas Sam Ratulangi \\ Email: d_saerang@unsrat.ac.id
}

\begin{abstract}
This study aims to analyze and discuss the effect of Transformational Leadership and Employee Integrity through Organizational Citizenship Behavior (OCB) On Employee Innovation at Regency / City Inspectorates in North Sulawesi Province. This research is a quantitative study, using a survey method with a causal approach, with data analysis techniques using Structural equation modeling (SEM) analysis. Research respondents are 200 employees at the District / City Inspectorate in North Sulawesi Province.

The results of this study indicate that 1) Transformational leadership has a direct and positive effect on employee innovation. The better the leadership at the regional Inspectorate adopts the transfrormational leadership style, the better the innovator will be at the regional inspectorate. 2) Integrity has a direct and positive effect on employee innovation. The more integrity with Government Internal Control Apparatus Regional Inspectorate, the better will be innovations in the field of supervision. 3) Organizational citizenship behavior (OCB) has a direct and positive effect on employee innovation. The better the Organizational Citizenship Behavior (OCB) of the Government Internal Control Apparatus Regional Inspectorates, the innovations of the Government Internal Control Apparatus in the field of supervision will also increase. 4) Transformational leadership has a direct and positive effect on organizational citizenship behavior (OCB). The better the leadership at the regional Inspectorate adopts the transformational leadership style, the more it increases organizational citizenship behavior $(O C B)$ from the Government Internal Control Apparatus. 5) Employee integrity has a direct and positive effect on organizational citizenship behavior (OCB). The more integrated the Government Internal Control Apparatus regional Inspectorate, the better the organizational citizenship behavior (OCB) of the Government Internal Control Apparatus. 6) Transformational leadership has an indirect and positive effect on employee innovation through organizational citizenship behavior (OCB). 7) Employee integrity has an indirect and positive effect on employee innovation through organizational citizenship behavior $(O C B)$.
\end{abstract}

Keywords: : Transformational Leadership, Integrity, Organizational Citizenship Behavior (OCB), Innovation.

Received: 8 February 2020;

Accepted: 8 April 2020;

Publish; June 2020.

How to Cite:

Hadi, P., Hamidah., \& Saerang, D.P. (2020). The Influence of Transformational Leadership and Employee Integrity through Organizational Citizenship Behavior (OCB) on Employee Innovation in Regency / City Inspectorates In North Sulawesi Province. Journal of Business and Behavioural Entrepreneurship, 4(1), 81-90. https:// doi.org/10.21009/JOBBE.004.1.06 


\section{INTRODUCTION}

Inspectorate institutions especially in regencies/cities really need employees who have the ability to innovate. Regency/City Inspectorate Institution has the main task of supervising the implementation of Regency/City regional government. If in carrying out this task the employee does not have adequate innovation and competence in accordance with his role and function, the existence of the institution will be 'barren'. This has become a phenomenon in the community that tends to 'distrust' the Regency / City inspectorate agency.

Based on the results of the pre-survey regarding the influence of transformational leadership, the following data are obtained: the average value of respondents' answers, namely 2.4 or answer disagreed, the initial conclusion was found that leaders generally do not have charisma in leading, not fully able to inspire employees, do not have the ability to intellectual stimulation of employees and have not been able to provide personal attention, please workers, train and advise employees. According to Bass and Avolio in Hakim (2012) revealed that transformational leadership is one important dimension in effective leadership which is also the strongest predictor of leadership outcomes, such as the extra effort of subordinates to the organization, satisfaction with leaders, and assessment subordinate to leadership skills.

The results of the next pre survey regarding integrity obtained the following data: the average value of the respondent's answer is 2.4 or answer disagreed, so the initial conclusion was found that not all the apparatus in the Inspectorate adhere to the principles in carrying out supervisory duties, as well as the behavior of the apparatus who carry out supervisory duties do not all have honorable and honest behavior. For courage, not all apparatuses are brave in taking firm actions at the time of the assignment. Furthermore, not all apparatuses in carrying out supervisory tasks are carried out based on belief in their knowledge and sometimes in carrying out the duties of the apparatus are still following emotions in the sense of not acting rationally.

For the OCB variable, the average value of the respondent's answer is 2.4 or answer disagreed, the initial conclusion found that in dealing with problems the leadership has not given confidence to subordinates in solving the problems encountered regarding task completion, compliance with state civil service regulations is still lacking, tolerance of the state civil apparatus to changes in the organization is not good enough, the state civil apparatus has not been able to avoid conflicts that occur within the organization, concern among fellow colleagues is still quite low, the state civil apparatus is also not able to fully implement virtues in the organization and have not been fully able to apply good manners, and not yet fully able to provide assistance to fellow colleagues. According to Al-Mahasneh (2015) showed that the OCB factors have an impact on job performance. This means that the perception of employees toward OCB has a positive and significant influence on employees performance. The OCB factors have an impact on work volume, on work quality, employee-colleagues relationship as a dependent variable and on employee-higher level relationships.

The results of the pre-survey further concern employee innovation, data obtained the average value of respondents' answers that is 2.4 or answer disagree, then the initial conclusion was found that the leadership has not been able to provide support so that subordinates are able to create ideas / programs, implement ideas / programs in the organization and also evaluating ideas / programs. Cooperation between leaders and subordinates has also not been well established as well as the commitment of the state civil apparatus for the successful achievement of the organization's vision and mission is still not strong. For individual psychological capital, one of which is

* The Influence of Transformational Leadership and Employee Integrity through Organizational Citizenship Behavior (OCB) on Employee Innovation in Regency / City Inspectorates In North Sulawesi Province 
seen from the ability to find solutions to long-term problems, it is found that not all state civil apparatuses have the ability to find solutions to long-term problems. The atmosphere of organizational innovation is also not good because harmony in the work environment is not good so it has not been able to support the improvement of the work of the civil service.

Based on the facts above, the researcher is interested in conducting research on: "The effect of transformational leadership, employee integrity, and organizational citizenship behavior (OCB) on employee innovation at the District / City Inspectorate in North Sulawesi Province".

\section{LITERATURE REVIEW}

\section{Employee Innovation}

Innovation is one aspect that influences the development of an organization. Some organizations both private sector and public sector organizations such as government organizations are trying to find innovations. Innovation according to Said (2007: 27 ) is interpreted as a planned change by introducing technology and the use of new equipment within the scope of agencies. Innovation has an understanding that is not only limited to building and updating but can also be broadly defined, utilizing new ideas creating products, processes, and services (Susanto, 2010: 158).

\section{Transformational leadership}

Transformational leadership according to Robbins (2015: 63) is leadership that gives appreciation and intellectual stimulation that is individualized and has charisma. Transformational leadership is often interpreted as true leadership because this leadership really works towards goals at the organizational level to a goal that has never been achieved before. Transformational leadership is built on top of transactional leadership so that it can produce a level of effort and performance of subordinates that goes beyond what happens with just a transactional approach.

\section{Integrity}

According to Mulyadi (2008: 145) integrity is the ability of people to realize what has been said or promised by that person into a reality. Arens et al (2008: 99), integrity means that someone acts according to their conscience, in any situation. Integrity is the concept of consistency in actions, values, methods, steps, principles, expectations and results that connotes a deep commitment to doing the right thing for the right reasons, regardless of the circumstances.

\section{Organizational Citizenship Behavior}

Bateman and Organ are the figures who first used the term OCB, namely in 1983. The definition of OCB is beneficial behavior carried out by employees, free from the provisions or obligations with the aim of helping others in achieving organizational goals (Garg and Rastogi, 2006: 573).

\section{RESEARCH METHOD}

This research is a quantitative study, using a survey method with a causal approach, with data analysis techniques using Structural equation modeling (SEM) analysis. This analysis is used to examine the interrelationship between research variables, as well as measuring the effect of three exogenous variables on one endogenous varia-

\footnotetext{
* The Influence of Transformational Leadership and Employee Integrity through Organizational Citizenship Behavior (OCB) on Employee Innovation in Regency / City Inspectorates In North Sulawesi Province 
ble, namely: the direct influence of transformational leadership $\left(\mathrm{X}_{1}\right)$, employee integrity $\left(\mathrm{X}_{2}\right)$ and Organizational Citizenship Behavior $(\mathrm{OCB})\left(\mathrm{X}_{3}\right)$ on Employee Innovation $(\mathrm{Y})$.

The constellation of research can be described as follows:

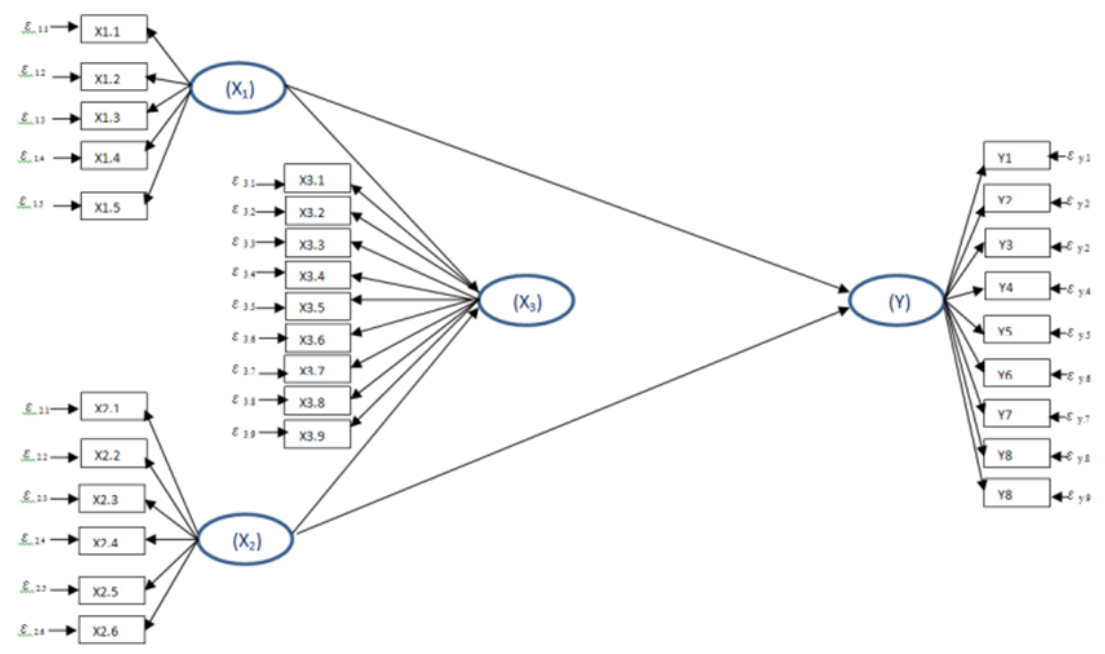

\section{RESULTS AND DISCUSSIONS}

\section{Structural model: testing hypotheses}

The structural model contains the path analysis which is the basis for proving hypotheses that have been prepared previously.

Table 1. Regression Coefficient

\begin{tabular}{|l|l|l|r|l|}
\hline & & & Estimate & Label \\
\hline $\mathbf{x 3}$ & $\begin{array}{l}<- \\
--\end{array}$ & x2 & .753 & par_13 \\
\hline $\mathbf{x 3}$ & $\begin{array}{l}<- \\
--\end{array}$ & x1 & .374 & par_15 \\
\hline $\mathbf{y}$ & $\begin{array}{l}<- \\
--\end{array}$ & x3 & .429 & par_12 \\
\hline $\mathbf{y}$ & $\begin{array}{l}<- \\
--\end{array}$ & x2 & .364 & par_14 \\
\hline $\mathbf{y}$ & $\begin{array}{l}<- \\
--\end{array}$ & x1 & .278 & par_16 \\
\hline
\end{tabular}

Source: Processed Data

* The Influence of Transformational Leadership and Employee Integrity through Organizational Citizenship Behavior (OCB) on Employee Innovation in Regency / City Inspectorates In North Sulawesi Province 
For the regression coefficient :

1. Transformational leadership (X1) has a regression coefficient of 0.278 for employee innovation $(\mathrm{Y})$, meaning that the higher or better the transformational leadership, the higher or better employee innovation and vice versa.

2. Integrity (X2) has a regression coefficient of 0.364 for employee innovation (Y), meaning that the higher or better the employee integrity, the higher or better employee innovation and vice versa.

3. Organizational citizenship behavior (OCB) (X3) has a regression coefficient of 0.429 on employee innovation (Y), meaning that the higher or better organizational citizenship behavior (OCB), the higher or better employee innovation (Y) and vice versa.

4. Transformational leadership (X1) has a regression coefficient of 0.374 against organizational citizenship behavior (OCB) (X3), meaning that the higher or better transformational leadership (X1), the higher or better organizational citizenship behavior (OCB) (X3) and vice versa.

5. Integrity (X2) has a regression coefficient of 0.753 against organizational citizenship behavior (OCB) (X3), meaning that the higher or better the integrity, the higher or better organizational citizenship behavior (OCB) (X3) and vice versa.

Table 2. Structural Model or path analysis (hypothesis testing)

\begin{tabular}{|l|l|l|r|r|r|r|l|}
\hline & & & Estimate & S.E. & C.R. & P & Label \\
\hline x3 & $<---$ & x2 & .753 & .103 & 7.324 & $* * *$ & par_13 \\
\hline x3 & $<---$ & x1 & .374 & .091 & 4.112 & $* * *$ & par_15 \\
\hline $\mathrm{y}$ & $<---$ & x3 & .429 & .107 & 4.008 & $* * *$ & par_12 \\
\hline $\mathrm{y}$ & $<---$ & x2 & .364 & .110 & 3.309 & $* * *$ & par_14 \\
\hline $\mathrm{y}$ & $<---$ & $\mathrm{x} 1$ & .278 & .084 & 3.330 & $* * *$ & par_16 \\
\hline
\end{tabular}

Source: Processed Data

For hypothesis testing :

Hypothesis 1. Transformational leadership (X1) has a direct and positive effect on employee innovation (Y), as evidenced by having a probability level below $5 \%(0,000)$ and a positive direction.

Hypothesis 2. Integrity (X2) has a direct and positive effect on employee innovation (Y). proven because it has a probability level under $5 \%$ $(0,000)$ and a positive direction

Hypothesis 3. Integrity (X2) has a direct and positive effect on employee innovation $(\mathrm{Y})$. proven because it has a probability level under $5 \%$ $(0,000)$ and a positive direction

Hypothesis 4. Transformational leadership (X1) has a direct and positive effect on organizational citizenship behavior (OCB) (X3). proven because it has a probability level under 5\% (0.00) and positive direction

Hypothesis 5. Employee integrity (X2) has a direct and positive effect on organizational citizenship behavior (OCB) (X3) as it is proven to have a probability level below $5 \%(0.00)$ and a positive direction.

* The Influence of Transformational Leadership and Employee Integrity through Organizational Citizenship Behavior (OCB) on Employee Innovation in Regency / City Inspectorates In North Sulawesi Province 
Table. 3 Indirect Effect

\begin{tabular}{|l|r|r|r|r|}
\hline & $\mathrm{x} 2$ & $\mathrm{x} 1$ & $\mathrm{x} 3$ & $\mathrm{y}$ \\
\hline $\mathrm{x} 3$ & .000 & .000 & .000 & .000 \\
\hline $\mathrm{y}$ & .323 & .160 & .000 & .000 \\
\hline
\end{tabular}

\section{Source: Processed Data}

Indirect the biggest effect in this research model was contributed by employee Integrity (X2) on Employee Innovation (Y) of 0.323.

For hypotheses involving indirect elements, they use several stages of analysis because there must be significant requirements on each direct path to be tested for their indirect relationships. And for the arguments summarized in the table below :

Table 4. Relationship Test

\begin{tabular}{|c|c|c|c|c|c|}
\hline Hypothesis tested & $\begin{array}{l}\text { Must be a significant } \\
\text { direct relationship } 1\end{array}$ & $\begin{array}{l}\text { Must be a significant } \\
\text { direct relationship } 2\end{array}$ & $\begin{array}{l}\text { Must be a signifi- } \\
\text { cant direct rela- } \\
\text { tionship } 3\end{array}$ & $\begin{array}{l}\text { The value } \\
\text { and direc- } \\
\text { tion of the } \\
\text { indirect re- } \\
\text { lationship }\end{array}$ & Conclusion \\
\hline $\begin{array}{l}\text { Hypothesis } 6 . \\
\text { Transformational } \\
\text { leadership has an indirect } \\
\text { and positive effect on } \\
\text { employee innovation } \\
\text { through organizational } \\
\text { citizenship behavior } \\
\text { (OCB). }\end{array}$ & $\begin{array}{l}\text { Transformational } \\
\text { leadership towards } \\
\text { innovation: } \\
\text { Finding: significant }\end{array}$ & $\begin{array}{l}\text { Transformational } \\
\text { leadership towards } \\
\text { organizational } \\
\text { citizenship behavior } \\
\text { (OCB).: } \\
\text { Findings: } \\
\text { Significant }\end{array}$ & $\begin{array}{l}\text { organizational citi- } \\
\text { zenship behavior } \\
\text { (OCB) towards } \\
\text { innovation: } \\
\text { Findings: } \\
\text { Significant }\end{array}$ & $\begin{array}{l}0.160 \text { and } \\
\text { positive }\end{array}$ & be accepted \\
\hline $\begin{array}{l}\text { Hipotesis } 7 . \\
\text { Employee Integrity has } \\
\text { an indirect and positive } \\
\text { effect on employee inno- } \\
\text { vation through organiza- } \\
\text { tional citizenship behav- } \\
\text { ior (OCB). }\end{array}$ & $\begin{array}{l}\text { Employee Integritiy } \\
\text { towards innovation: } \\
\text { Findings: } \\
\text { Significant }\end{array}$ & $\begin{array}{l}\text { Employee integrity } \\
\text { towards organizational } \\
\text { citizenship behavior } \\
(\mathrm{OCB}) .: \\
\text { Findings: } \\
\text { Significant }\end{array}$ & $\begin{array}{l}\text { organizational citi- } \\
\text { zenship behavior } \\
\text { (OCB) towards } \\
\text { innovation:: } \\
\text { Findings: } \\
\text { Significant }\end{array}$ & $\begin{array}{l}0.323 \text { dan } \\
\text { positive }\end{array}$ & be accepted \\
\hline
\end{tabular}

\section{Discussion}

Based on the results of testing statistical research hypotheses. The research findings are explained descriptively and verification, which are then compared with the theories and results of previous studies.

\section{Hypothesis 1 Transformational leadership has a direct and positive effect on employee innovation .}

The results showed that the first hypothesis was accepted. Transformational leadership (X1) has a direct and positive effect on employee innovation (Y), as evidenced by having a probability level below $5 \%(0,000)$ and a positive direction.

The results of the study prove empirically that transformational leadership influences employee innovation. The results of research that prove that transformational leadership influences employee innovation is research conducted by Pratama (2015: 13). The results of his research that 1) Transformational leadership has a positive and

* The Influence of Transformational Leadership and Employee Integrity through Organizational Citizenship Behavior (OCB) on Employee Innovation in Regency / City Inspectorates In North Sulawesi Province 
significant influence on innovative behavior directly, 2) Organizational climate is proven as a variable that fully mediates the effect of transformational leadership on innovative behavior.

\section{Hypothesis 2 Integrity directly and positively influences employee innovation.}

The results showed that the second hypothesis was accepted. Integrity (X2) has a direct and positive effect on employee innovation (Y), as evidenced by having a probability level below $5 \%(0,000)$ and a positive direction.

The results of research from Gunayanthi (2015: 193) suggest that integrity has a positive effect on auditor performance. This shows that when the auditor's integrity is higher, this will improve the quality of the audit and will further improve the auditor's performance itself. One of the intended performance of auditors is how the auditor is able to innovate in producing quality audit results. Continuously improve professional skills, effectiveness, and quality of supervision. In order for the auditor's performance to improve automatically the audiorial behavior must reveal: 1) have the initiative and a strong will to learn without being instructed or not waiting; 2) willing to follow a training program organized by his institution or other agency; and 3) always learning new knowledge and technology that is directly or indirectly related to the workload and innovating work methods and methods in accordance with the changing times.

\section{Hypothesis 3 Organizational citizenship behavior (OCB) has a direct and positive effect on employee innovation.}

The results showed that the third hypothesis was accepted. Organizational citizenship behavior (OCB) (X3) has a direct and positive effect on employee innovation (Y), proven because it has a probability level below $5 \%(0,000)$ and a positive direction.

The results of the study prove empirically that organizational citizenship behavior (OCB) affects employee innovation. According to Logahan et al (2014: 396) that innovative behavior increases when there is OCB implementation in a company. The benefits of organizational citizenship behavior (OCB) are very great for organizations, including the following, according to Organ (2006: 199): 1) OCB can increase the productivity of coworkers; 2) OCB is also able to increase manager productivity; 3) OCB can save resources owned by management and the organization as a whole; 4) OCB becomes an effective means to effectively coordinate work team activities; 5) OCB improves the organization's ability to recruit and retain employees with good quality performance; 6) OCB can maintain organizational performance stability; 7) OCB helps the organization's ability to survive and adapt to changing environments.

\section{Hypothesis 4, transformational leadership (X1) has a direct and positive effect on organizational citizenship behavior (OCB) (X3).}

The results showed that the fourth hypothesis was accepted. transformational leadership (X1) has a direct and positive effect on organizational citizenship behavior (OCB) (X3). proven because it has a probability level under 5\% (0.00) and positive direction.

The results of the study prove empirically that transformational leadership influences organizational citizenship behavior (OCB). Gunawan (2016: 60) argues that leadership is one that can influence OCB behavior because without effective leadership from a leader, a company will experience a setback. Each leader basically has a different behavior in leading or often referred to as a leadership style. The leadership style that is carried out by a leader in influencing the behavior of others according to

* The Influence of Transformational Leadership and Employee Integrity through Organizational Citizenship Behavior (OCB) on Employee Innovation in Regency / City Inspectorates In North Sulawesi Province 
his desires is influenced by the nature of the leader himself. Employees have leaders who serve as directors for these employees to act in accordance with company goals. One of the leadership styles that are suitable today is the transformational leadership style. In a broad sense, leadership can be used by everyone and is not only limited in force in a particular organization or office. Leadership is an activity to influence the behavior of others, or the art of influencing human behavior both individuals and groups. Leadership does not have to be limited by bureaucratic rules or karma. Leadership does not have to be bound in a particular organization, but leadership can happen anywhere as long as someone shows his ability to influence others towards the achievement of a certain goal (Thoha, 2004: 9).

\section{Hypothesis 5 Employee integrity (X2) has a direct and positive effect on organizational citizenship behavior (OCB) (X3).}

The results showed that the fifth hypothesis was accepted. Employee integrity (X2) has a direct and positive effect on organizational citizenship behavior (OCB) (X3) as it is proven to have a probability level below $5 \%(0.00)$ and a positive direction.

The results of the study prove empirically that employee integrity influences organizational citizenship behavior (OCB). Research conducted by Husodo (2018: 1) that organizational culture is culture where he is like values (these values include responsibility, integrity, can adapt to the environment and work situations, fair treatment, and friendliness), beliefs, and social or community behavior which then produces social culture or community culture influences Organizational Citizenship Behavior (OCB).

\section{Hypothesis 6 Transformational leadership (X1) has an indirect and positive effect on employee innovation (Y) through organizational citizenship behavior (OCB) (X3).}

The results showed that the sixth hypothesis was accepted. Transformational leadership (X1) has an indirect and positive effect on employee innovation (Y) through organizational citizenship behavior (OCB) (X3) proven.

The results of this study are in line with research conducted by Sekar et al (2017: 3161) that transformational leadership has a positive and significant effect on Organizational Citizenship Behavior. Transformational leadership is a factor that influences the attitudes, perceptions and behavior of employees to then be used as motivation in improving OCB. Organizational Citizenship Behavior (OCB) contributes to the organization in the form of increasing colleague productivity, increasing manager productivity, saving resources owned by management and the organization as a whole, helping to maintain group functions, being effective in coordinating work group activities, increasing organizational capability to attract and retain the best employees, improve the stability of the work of the organization, improve the ability of the organization to adapt to changing environments (Podsakoff and Mackenzie in Kelana, 2009: $60)$.

Jahangir (in Yusrin, 2014) argues that leadership style has a strong influence on the willingness of employees to be involved in OCB. Leaders who have creativity, innovation, and high flexibility will have a positive impact on transformational leadership. In addition, leaders must also inspire and motivate their subordinates to work better and prioritize organizational interests rather than personal interests.

OCB and employee innovation have a close relationship. According to Logahan et al (2014: 397) that innovative behavior (innovative behavior) is one of the behaviors

* The Influence of Transformational Leadership and Employee Integrity through Organizational Citizenship Behavior (OCB) on Employee Innovation in Regency / City Inspectorates In North Sulawesi Province

* $\quad$ https://doi.org/10.21009/JOBBE.004.1.06 
that affect OCB. Innovative behavior is defined as overall individual actions that lead to the emergence, recognition and application of something new and beneficial at all levels of the organization.

Hypothesis 7 Employee Integrity (X2) has an indirect and positive effect on employee innovation (Y) through organizational citizenship behavior (OCB) (X3).

The results showed that the seventh hypothesis was accepted. Employee Integrity (X2) has an indirect and positive effect on employee innovation (Y) through organizational citizenship behavior (OCB) (X3) proven.

The results of research from Rahayu (2017: 49) that integrity has a direct positive effect on organizational citizenship behavior (OCB). Integrity is consistency between values and actions. People with integrity will act consistently in line with values, code of ethics, and organizational and / or professional policies, even in difficult circumstances to do so. Integrity is also defined as a personality that is based on an honest, courageous, wise, and responsible element to build trust in order to provide a basis for reliable decision making. When linked to a code of ethics, integrity is defined as consistent action, in accordance with organizational policies and codes of ethics. Conceptually, integrity and ethical values clearly have a positive influence on organizations and individuals.

\section{CONCLUSION AND RECOMMENDATION}

Based on the results of research and discussion in the previous chapter, it can be concluded several things, namely, 1) transformational leadership directly and positively influences employee innovation. The better the leadership at the regional Inspectorate adopts the transfrormational leadership style, the better the innovator will be at the regional inspectorate, 2) integrity has a direct and positive effect on employee innovation. The more integrity with APIP Regional Inspectorate, the better will be innovations in the field of supervision, 3) organizational citizenship behavior (OCB) has a direct and positive effect on employee innovation. The better the Organizational Citizenship Behavior (OCB) of the APIP Regional Inspectorates, the innovations of the APIP in the field of supervision will also increase, 4) transformational leadership directly and positively influences organizational citizenship behavior (OCB). The better the leadership at the regional Inspectorate adopts the transformational leadership style, the more it increases organizational citizenship behavior (OCB) from the APIP, 5) employee integrity has a direct and positive effect on organizational citizenship behavior (OCB). The more integrated the APIP regional Inspectorate, the better the organizational citizenship behavior (OCB) of the APIP, 6) transformational leadership has an indirect and positive effect on employee innovation through organizational citizenship behavior (OCB),7) employee integrity has an indirect and positive effect on employee innovation through organizational citizenship behavior (OCB).

\section{REFERENCES}

Arens, A. A. Elder, Randal, J dan Beasley, Marks S. 2008. Auditing dan Jasa Assurance. Jilid 1. Edisi Keduabelas. Jakarta : Erlangga.

Garg, P. and R. Rastogi. 2006. New model of job design: Motivating employees' performance. Journal of Management Development, 25(6), DOI $10.1108 / 02621810610670137$.

Gunayanthi, A. 2015. Pengaruh Integritas, Obyektivitas, Kerahasiaan dan Kompetensi Pada Kinerja Auditor Inspektorat Kota Denpasar. E-jurnal Akuntansi Uni-

* The Influence of Transformational Leadership and Employee Integrity through Organizational Citizenship Behavior (OCB) on Employee Innovation in Regency / City Inspectorates In North Sulawesi Province

* $\quad$ https://doi.org/10.21009/JOBBE.004.1.06 
versitas Udayana.

Gunawan, R., 2016. Pengaruh Kepemimpinan Transformasional Terhadap Organizational Citizenship Behavior(OCB) Pada Pt First Marchinery Tradeco Cabang Surabaya. AGORAVol. 4, No. 1, (2016). P : 66.

Husodo, Y. R. P.. 2018. Pengaruh Budaya Organisasi Terhadap Organizational Citizenship Behavior (OCB) Dengan Kepuasan Kerja Sebagai Variabel Intervening Pada Pt Jatim Indo Lestari.AGORA Vol. 6, No. 1, (2018).

Kelana, Ludy. 2000. Pengaruh Kepuasan Kerja dan Komitmen Organisasi terhadap Organizational Citizenship Behavior (OCB). Sinergi, Kajian Bisnis dan Manajemen, 11(1):59- 75.

Logahan, J. M., Indrajaya, A. Dan Proborini, A. W. 2014. Analisis Pengaruh Perilaku Inovatif Dan Self - Esteem Terhadap Organizational Citizenship Behavior Di PT. Stannia Binekajasa. Binus Business Review Vol. 5 No. 1 Mei 2014.

Mulyadi. 2008. Sistem Akuntansi. Jakarta: Salemba Empat.

Organ, D. W., P. M. Podsakoff, dan Scott B. MacKenzie. 2006. Organizational Citizenship Behavior, Its Nature, Antecendents, and Consequences. California: Sage Publications, Inc.

Pratama, A. 2015. Pengaruh Kepemimpinan Transformasional Terhadap Perilaku Inovatif Karyawan Dengan Iklim Organisasi Sebagai Variabel Mediasi (Studi Pada Pemerintah Kota Mataram). Program Studi Magister Manajemen Program Pasca Sarjana Universitas Atma Jaya Yogyakarta.

Rahayu. E. S., 2017. Pengaruh Budaya Kerja, Integritas Dan Kepercayaan Terhadap Organizational Citizenship Behavior Pada Dosen Universitas Negeri Jakarta. Ecnosains Volume XV hal : 36-54.

Robbins, S. 2015. Organizational Behavior, $9^{\text {th }}$ Edition. New Jersey: Precentice Hall International Inc.

Said, M. M. 2007. Birokrasi di Negara Birokratis. Malang: UMM Press.

Sekar, N. K. A, A.A S. K. Dewi, dan K. Ardana. 2017. Pengaruh Kepemimpinan Transformasional Dan Komunikasi Terhadap Organizational Citizenship Behavior Di Hotel Inna Grand Bali Beach. E-Jurnal Manajemen Unud, Vol. 6, No. 6, 2017: 3139-3167.

Susanto. 2010. 60 Management Gems. Jakarta: Kompas.

Thoha, M. 2004. Perilaku Organisasi, Jakarta: PT. Raja Grafindo Persada.

Yusrin, K. 2014. Hubungan Antara Kepemimpinan Transformasional Dengan Organizational Citizenship Behavior (OCB) Di Universitas Muhammadiyah Surakarta (UMS). Fakultas Psikologi. Universitas Muhammadiyah Surakarta.

* The Influence of Transformational Leadership and Employee Integrity through Organizational Citizenship Behavior (OCB) on Employee Innovation in Regency / City Inspectorates In North Sulawesi Province 